\title{
You don't belong here: Blood and Chocolate and British Rituals of Remembrance
}

\begin{abstract}
This article argues that the promenade theatre project Blood and Chocolate (York, 2013) offered a theatrical rebuttal to widespread British revisionist, celebratory views of the First World War that draw authority from annual remembrance rituals such as poppy-wearing and the two minute silence. Building on Richard Schechner's argument that rituals 'make belief' I propose that over time, remembrance rituals may be used to make - or remake - history. This history does not come from the past, but exploits an idea of the past for contemporary political gain. By contrast, Blood and Chocolate dramatized aspects of history but emphasised its own theatricality in order to stress the absolute separateness of past and present.
\end{abstract}

\section{A MOMENT.}

It's mid October 2013, about 9 o'clock at night. I'm standing in York city centre, one of a large crowd of spectators at the open-air production of Blood and Chocolate, a promenade performance by the York Theatre Royal, Slung Low and Pilot Theatre companies. The production boasts an enormous cast of volunteer actors who guide us around the streets in period costume, telling a story about local men who went off to fight in the First World War, and the women who took up their places at the Rowntree's Chocolate Factory. Each spectator receives a tin containing chocolate, redolent of the Christmas ration sent to soldiers in the trenches and which, alongside the forthcoming slaughter, gives the production its name. The show begins outside the Theatre Royal with a projected film full of pomp and patriotism, and as we process through the streets children wave flags and couples kiss their goodbyes. As the show develops we hear letters from the trenches read aloud, their initial optimism studded with increasingly audible notes of doubt and panic. By the time we reach Parliament Street, York's central commercial avenue, the characters have lost their enthusiasm and the mood is one of numb, disorganized terror.

Parliament Street is broad and spacious, so the 200-strong crowd are fanned out by the baton wielding ushers until we are four or five deep, and as we walk the length of the street, cannons are wheeled around whilst uniformed men shout inaudible orders amidst the gunfire. Parked at the end of the street is an unmarked cargo trailer. We approach, and we are told to stop. Abruptly, the side of the trailer falls away, and behind is a replica trench, strewn with the bodies of dead or dying soldiers, tended under the sound of the shells by a handful of nurses. We pause for a moment before one of the nurses turns to us and says, very courteously, "Ladies and Gentlemen: you don't belong here". The words are conveyed directly from her radio mic to the robust, noise cancelling 'bucket' headphones with which each of us has been provided. We are manhandled by the ushers into a church, where we are fed hot chocolate and a festive sermon is delivered before we are sent out again to experience the rest of the production. But in the few seconds between the nurse's dismissal and my actual movement, I realise that I have been revealed to myself as a trespasser. I do not belong here; and yet here I am. The realization is accompanied by a feeling of profound discomfort, and the moment develops a quality of vague but intense significance.

The moment I have just described provides the point of departure for my discussion in this article. The implications offered by that single moment are formidably complex, so in order to moderate the complexity I will offer three statements to define my analysis. The first is that because of the subject matter, spatio-temporal location and emphasis upon public participation, the moment intersects with a performance discourse that I am advisedly calling 'British Rituals of Remembrance'. My reasons for adopting this rather contentious term will be explained momentarily. The second statement is that if we compare this moment with the annually observed two minutes silence that constitutes perhaps the most prominently collective British Ritual of Remembrance, we may notice a critical difference in their approaches to the idea of participation. The third statement is that this difference opens up an important discussion about British Rituals of Remembrance in general, and the 
functions that they have assumed in our current time period, a century after the First World War took place. An elaboration of each of these statements forms the structure of this article.

Blood and Chocolate was one of a vast amount of local, regional and national projects undertaken from 2013 onwards to mark various centenary milestones of the First World War. These have ranged from $\mathrm{BBC}$ documentaries to battle recreations, public vigils to school field trips. Alongside these specially commissioned acts of commemoration, of course, there are a set of practices that are annually performed across Great Britain, whose purpose is to publicly observe the death in combat of British service men and women in conflicts from the First World War to the present. They take place mostly in the month of November and particularly on the 11th Remembrance Day. They include poppy-wearing, military pageants, public speeches and the nationally observed two minutes silence. For the purpose of this study I have grouped these practices under the heading British Rituals of Remembrance, a term that merits careful consideration.

\section{BRITISH RITUALS OF REMEMBRANCE}

\section{remembrance, $n$.}

2.

a. The memory (†or thought) which a person has of a thing or person; the act or fact of remembering a thing or person.

b. A recollection, a reminiscence; an act of remembering.

c. The memory of a person who has died or a thing of the past surviving in the minds of others.

Among the definitions given by the Oxford English Dictionary to 'remembrance' the three listed here are of particular importance. The first two emphasise remembrance as an act of memory, an act that is done, and done in the present tense. By doing or acting memory, a connection is assumed between the present and past, a channel or rift opened up in the former that may then give rise to some echo or ghost of the latter. The third definition extends this idea, and reaffirms the connection between the past and present as one that can outlive the death of a subject. Put together, 'remembrance' thus indicates an act by which memory is employed in order to bring some version of the dead back into the present, as in the act of remembering a former acquaintance who has now passed away. But the act is not restricted to individual recollection - we can $d o$ memory without possessing it, which is precisely the function of remembrance that has been superimposed into contemporary British usage. In Britain, in 2015, the term 'remembrance' has an inescapable connection to the death of soldiers in combat.

Thus, speaking of 'remembrance' in this contemporary context, I am making a set of assumptions. I assume, for example, an idea of 'memory' that is not singular but collective, a memory that can be summoned and shared in an act of participation. I am following Maurice Halbwachs' (1992) arguments that memory is not restricted to the things that a person can remember, but can extend beyond the reach of personal, even living, recollection. A range of strategies can be used to accomplish this - everything from oral tradition to digital recording - I want to focus on one particular strategy here, which is the investiture of memory in objects. Marianne Hirsch has written extensively on this, and she often sees what she calls 'testimonial' objects such as diaries, letters and paintings as an invaluable means for engaging with experiences of the past. She notes that such objects can 'carry memory traces from the past to the present, and also [...] embody this transmission' (3). Hirsch's objects are autographic - their value as an object of memory resides in their singularity and their connection to the past. In an act of remembrance, however, such connections may be secondary, or even immaterial to the object's principal function. In his study of the War Memorials of East Kent, for example, Peter Donaldson (2006) discusses the first officially recognised public memorial in Folkestone, which was a message carved onto the lid of a box and then propped against a wall by a nine year old schoolboy (3). The memorial did not come from the war, nor did its creator have first-hand experience or even (presumably) a particularly sophisticated understanding of the war. This is because remembrance, whilst it invokes history, is not historical in the sense that it does not need to come from, or involve an interrogation of, the past. The significance of the act of remembrance is derived from being done, and the role of the object in this act is to facilitate that doing. The red poppy, to use another example, was first invoked in connection with the First World War in John McRae's poem In Flanders Fields (1915), where the dead exhort the living 'take up our 
quarrel with the foe' or else 'we shall not sleep'. This call to violence hardly reflects current usage of the poppy as a token of solidarity - this is because the initial meaning has been blurred over by the repeated wearing of the poppies as an act of remembrance, an act which creates its own meaning. At this juncture, an act of remembrance may be considered in accordance with what Richard Schechner calls a ritual:

The actions in "ritual" are subscribed to for the duration of the ritual performance: I did not invent these actions, but in doing them, I am reinventing them. The doing of the actions draws me deeply into the actions without asking that I comprehend (at the moment of doing) what those actions signify. Or maybe I am simply the messenger: the rituals communicate in their own code, whether or not I understand the code. (783-784)

The experience of the ritual is subjective - one participant may be enthused by an action that leaves another unmoved - without affecting the success of the ritual at all. Thus one may wear a poppy without knowing why, or observe a two-minute's silence and think of nothing connected to the death of soldiers, and in either case the ritual is successfully performed. This does have troubling implications for the notion of a remembrance ritual as a form of collective memory, however, since it indicates that a memory may be reinvented and affirmed in the present without being consciously invoked by the participants. Returning to the poppy, this is exactly what the journalist Robert Fisk identified when he published an article in 2013 claiming that the wearing of poppies 'helps us avoid a search for the meaning of war' (Independent, 7 November 2013). If the wearing of poppies is ritualistic, then such a search is irrelevant to the overall function of the ritual. But if remembering something is not an essential part of a remembrance ritual, then can it be said with any specificity what that ritual is designed to do? A second of Schechner's observations uncovers some significance to this question:

In theatre, the subtext rules; while in ritual the text rules. Even empty or hollow rituals, if properly performed, "work", that is, accomplish what they are intended to do. Just because the bride wishes she weren't marrying does not undo what the ceremony and the signing of papers accomplish. [...] Ritual's actions are not make believe; they are "make belief": "invariant sequences of acts and utterances not encoded by the performers" enacted by "performers totally immersed in the proper execution of their complex tasks." The outcome is binding. (784-785)

The meaning of a ritual - that which is produced by its undertaking - may therefore have highly significant consequences for the performers, regardless of their intentions or comprehension of their own actions. The following example helps identify this phenomenon as it operates specifically within Remembrance Rituals. In May 2015, the current Labour leader Jeremy Corbyn refused to sing the National Anthem at a commemorative service for the Battle of Britain. The following description, taken from the Guardian, is very telling:

One onlooker at the service said they had watched Corbyn for several minutes as the national anthem was being sung and did not see his lips move. [...] Downing Street said the prime minister attached importance to the national anthem and was "very proud" to sing it. [...] A spokeswoman said: "The importance that the PM attaches to the national anthem is visible every time he is at one of these commemorative services. He is very proud and willing to join with others singing the national anthem."

The significant factor here is the act of reporting itself - both the 'onlooker' and the 'spokeswoman' demonstrate a degree of interest in their fellow participants that would seem to indicate that their own thoughts, at least, were not directed towards Battle of Britain. But that act of thinking is not part of the proper performance of the ritual, and thus their 'observance' is correct, even as they scrutinise those people around them. As Schechner argues, the 'text rules': it is what is done on the surface that counts, even when - as in this case - the judgements of Corbyn are legitimized by an appeal to the interior. Because he was not outwardly singing the song, the argument goes, he was not directing his thoughts to the proper places. Thus the ritual presumes some connection between present and past - 
present actions demonstrate engagement with past events. I spell out this formulation here as simply as possible because, as I will go on to argue, I believe it to be entirely specious. And what is more, that the authority granted to this specious relationship is extremely dangerous, because it opens up public credulity to political manipulation. In order to develop these arguments, I move to a discussion of my second statement.

\section{BLOOD + CHOCOLATE AND THE TWO MINUTES SILENCE}

The nationally observed 'two minute silence' on Remembrance Day, the $11^{\text {th }}$ November, is perhaps the greatest expression of collective remembrance in all of the rituals that are annually practiced in Britain. Synchronised by technical media, this ritual is observed simultaneously in public, educational and commercial spaces around the country. To use Schechner's terms, a 'proper performance' of this ritual involves not making any noise, moving as little as possible and, crucially, maintaining a sombre disposition, preferably with hands unoccupied and eyes downcast. It does not matter what participants think during these two minutes - the ritual requires only that this exterior be maintained. This crosses into a particular appreciation of the term 'performance', one that is concerned with semblance, or making something appear to be, in a way that does not intersect, and might even entirely contradict, the interiority of the act. The two-minute silence is a ritual whose 'proper' performance thus relies upon a dual meaning of 'observation' - the individual observes the ritual, and their observation is validated by being virtue of being observed.

But silence is a difficult phenomenon with which to engage, and presents us with awkward questions. What are the differences between 'active' or 'passive' silences; can one silence be engaged and another apathetic, and if they are then who can ever tell the difference? Thought cannot be mitigated, nor can the interiority of any act be guaranteed. Returning to the example of Corbyn - is this, as some critics believed, an inappropriate silence, or as some supporters argued is it in fact a more appropriate response to the stated objective of the commemoration than the observing in order to be observed' singing of the National Anthem? Clearly these issues cannot be solved here, but I'm going to pick up on two ideas that might assist in thinking about the role of silence in remembrance rituals. The first is the relationship between the public and the private in the two-minute silence, and the second is the question of disruption or interruption of silence and spectatorial engagement.

In considering other major rituals involving silence, such as prayer or meditation, it may be noticed that public observation is more often shunned in favour of the privacy that better serves an individual's ability to reflect and contemplate. But the 'proper performance' of the two-minute's silence prioritises the public, collective appearance. Consider, for example, the following two images. The first, published in the Daily Mail in November 2012, shows the heads of the three main political parties and PM, deputy PM and leader of the opposition David Cameron, Nick Clegg and Ed Milliband as well as former PMs Tony Blair and John Major, observing the ritual outside the Cenotaph in London. The second, published in the Daily Mirror on 8 May 2015, shows the same three men observing a public silence to commemorate the death of British soldiers in World War Two. In both photographs, the three men maintain the obligatory disposition and brandish a wreath of poppies apiece. What the images capture and reproduce are the observing in order to be observed, the prioritisation of the external in order to a) demonstrate that the political leaders of this country are fulfilling an obligation in the present and b) to serve as exemplar for the rest of the country to follow.

The first image carefully marks the solemnity of the occasion in the outward appearance of each of these figures, who are not participating in the ritual as individuals, but in ceremonial functions that are attributed by the offices that they held at the point of performance. This image, and its publication by the Daily Mail, undertakes some of the functions of a remembrance ritual in and of itself, one whose complexities I will now briefly try to unpack.

The image presents public figures engaged in a public ritual of remembrance, captured and disseminated to the public for our consumption. It does not matter what lies beneath the sombre expressions: all that matters is that the expressions appear sombre. Had one of the participants been captured smiling, this would have been considered unacceptable because it would break a central tenet of the ritual's proper performance. This would have been judged negatively by the press, and by inference therefore the public. This judgement is reflected in all public participations of this kind of ritual - one's performance is qualified, first and foremost, by how other people see you. It should also be acknowledged of course that the right-wing bias of the Daily Mail politically schematizes its conceptions of the 'proper' performance of a remembrance ritual. Their reporting of Corbyn's silence 
during the national anthem made hysterical and specious references to his 'sympathy for terror groups and Vladimir Putin'. (Daily Mail, 15 September 2015) Had Corbyn been captured smiling during the observation of a two-minute's silence ritual, the response of the Daily Mail would have been significantly more aggressive. But, of course, if Corbyn (or anyone else) was photographed smiling, that photograph would not be employed in the press to facilitate an act of remembrance, which is where we uncover further layers of significance. This image is an encouragement to 'us', the public, to act in accordance with the redoubtable example of our political leaders. In addition to being an act of remembrance, then, this is concurrently a reassertion of governmental hierarchies that has little to do with the professed intentions of the ritual itself. In its function as an example for 'us' to follow, the image fuses the ritual of remembrance with a reaffirmation of the British political mainstream, and thus we cannot engage with one without subscribing to the other. Here we encounter what might be called a politicization of the remembrance ritual that pushes beyond Schechner's valorisation of the ritual as ritual and opens up the 'binding' nature of the ritual to a limitless Other, in which we can be tied by our surface actions to a submerged agenda that is beyond our control, and potentially even our comprehension. In this case, I would venture to suggest that the obligation to perform the remembrance ritual is so strong not because of its intrinsic connection to the past, which as I have argued is at best negligible, but because of the repeated iterations of these rituals within the dominant spheres of British public life.

This is more clearly dramatized in this second photograph, which, although it records a similar ritual as the first, was not deployed by the Daily Mirror to support and encourage participation in remembrance. Instead, this image was printed in order to comment on a broader contextual detail that had nothing to do with World War Two. At the time this ritual was observed, and the photograph was taken, Labour and the Liberal Democrats had suffered huge defeats in the general election held the previous day, and Clegg and Miliband had both lost their positions as leaders. The article from the Daily Mirror was, ironically enough, entirely preoccupied with the interiority of the act of observation, though saw no contradiction between the supposed solemnity of the occasion and its speculations about what the three men might have been thinking at the time. There are further resonances in reprinting this image now, of course, as the three men in the second row, Boris Johnson, Michael Fallon and Philip Hammond currently hold high-profile cabinet positions whilst all three of the front row have seen their careers, in Cameron's words, 'end in failure'.

At the risk of oversimplifying the issue, here we encounter the principal difference that I believe was offered by the moment described in Blood + Chocolate. Rather than being publicly complicit in a mass performance of silence, the spectators were first individualised, as the bucket headphones through which the actors' voices were conveyed to us cut us off from each other. We were then presented with an image; the dead and dying soldiers in a trench. What could have been a tacky and voyeuristic conceit was transformed into something far more contemplative and affecting. The function of the dramatic image was not to somehow magically create a connection between the present and the past, so that spectators could better observe the suffering of generations before. Quite the contrary; it was used to remind us of our absolute separation from the past, and inability to access that suffering. Reflecting critically on this process, Hans-Thies Lehmann's ideas on the aesthetics of interruption are useful here:

We have to maintain the interruption, the caesura of the aesthetically-contemplative mode in theatre. Not that there is something intrinsically wrong with the latter. But in many ways it is worn out. [...] The aesthetic opportunity for intervention in the political lies elsewhere - notably, in variants of an interrupted aesthetic experience. (107)

This notion of a caesura speaks directly to the jolt of realization I experienced in Blood + Chocolate. As spectators, we were addressed in the moment of performance as a collective, but interrupted as individuals. Each of us was held in the peculiar isolation one gets from wearing headphones in a crowd, and though we were all hearing the same words, they cut through our responses to the fabricated image of suffering in front of us, forcing us to confront the actuality of our positions. We were trespassers from the present, we did not belong in the past. So in that moment, the caesura caused by the statement 'You don't belong here" pushed towards the notion of an 'intervention'. And for me, this was a moment of private awkwardness - I cannot speak for my fellow spectators, but I can affirm that at the point of interruption, I had no interest whatsoever in what they might have been doing. I could not have told you who was looking where, or what I could read in their expressions: I 
had been engaged by the performance's interaction with history precisely at the point at which I had been refused access to it. By pushing me away from the representation of death, Blood and Chocolate rejected the probing analysis of historiography in favour of concealing that which could not be shown. The untouchable otherness of this moment was accentuated by the vast spectacle of the surrounding performance: even (or particularly) accounting for the enormous effort to re-present narratives of the past, it was a place that we were incapable of accessing. What, then, to say about this experience, and how might it be positioned in response to my critique of remembrance rituals? In order to answer this, a closer reading of Lehmann's views on tragedy and the tragic experience is required.

Lehmann is concerned at one level with tracing the boundaries that divide the political and the theatrical as modes of creative expression. In a very broad definition, we might say that the political carries legitimacy by dint of a name (of law, of legislative process) and the theatrical constitutes an event occurring outside of any such process but in which the spectator has the "chance of an experience' with themselves. (89) This rather blunt description is intended merely to identify the criteria of efficacy upon which the two spheres are regulated. To be more blunt: the political is seen to be effective, the theatrical affective. This division stretches back to Aristotle, who read the Dionysian tragedies purely as aesthetic experiences. According to Lehmann, Aristotle - and thus the division between theatre and politics that has persisted ever since - was wrong. The tragedies were absolutely contingent on, and continued the functions of, the religious rituals that formed the basis of Greek society. Theatre and politics - or what Lehmann calls 'irresponsible artistic pleasure' and 'ethical [...] consideration and responsibility' - are blurred at the source. He goes on to argue in fact that blurring the theatrical and the political is at any and every given stage of history fundamental to the "proper" functioning of both discourses. Without that blurring, both theatre and politics are deprived of their counterbalances and robbed of contextual legitimacy. This is how he arrives at the significance of the caesura. In a time such as ours, where despite numerous efforts and projects to the contrary the aesthetic and political are often perceived as being hygienically distinct, an active intervention is required to create a 'grey zone' between them. In such zones, the erroneous separation of the spheres may temporarily be challenged, the 'certainties' potentially dissolved.

Conceiving of the theatrical and political as indispensable to one another is a familiar argument, and can often seem like nothing more than a plea for special dispensation. Edward Bond, for example, takes up this theme on a very grandiose scale when he declares that 'drama fashions our consciousness. All great civilizations create the drama that sustains them. And a civilization is created when it comes to terms with its past'. (Bond 2012) But in the localised example of the remembrance rituals, which sit on an intersection of theatre and politics, any attempt to argue that the two spheres are not indispensable to one another constitutes a fundamental (and dangerous) misconception of the rituals themselves. As I have attempted to point out, both the theatrical and political elements of the rituals are now commonly reduced to surface level caprices which disregard the fact that a) politically the rituals bind us to unseen narratives in the present and b) theatrically the rituals efface consideration of their stated point of reference. Wearing a poppy, for instance, produces in the present a 'meaning' of solidarity and support which, as Fisk argues, 'helps us avoid searching for meaning in war'. These two problems both need addressing and are both, as I will seek to outline in a discussion of my third statement, of significant importance.

\section{SOME DANGERS WITH RITUALISING HISTORY}

I have argued that although they do not engage with the events of the past, British rituals of remembrance wield considerable power by appearing to do just that, and through this appearance exact the annual participation of the general public. But so what? Schechner celebrates the quality of the ritual as ritual, and notes a huge potential to personal experience of undertaking rituals that one may not understand at the point of performance. Lehmann, for his part, valorises the function of ritual in the formation of theatrical tradition. Even if the remembrance rituals do not for the most part promote an active engagement with history, they still revive a sense of the First World War and subsequent conflicts, renewing the names of these events within a contemporary culture.

It would be a mistake, however, to see the remembrance rituals as somehow insulated against the vicissitudes of those cultures. Though they are not bound to the events of the past, they are vulnerable to the ideologies of their performance environments, and play in to narratives of nationalism, militarism and the affirmation of political and social hierarchies. From this angle, the erroneous belief that these rituals offer an engagement with the past becomes a lot more troubling, as it can be used to 
grant authority to politically motivated narratives or views about those events. The following source has been selected as merely one possible example of such a view. On the second of January 2014, the Daily Mail published an opinion piece entitled "Why does the Left insist on belittling true British heroes?" The article claimed, among other things, that:

Our understanding of the [First World] war has been overlaid by misunderstandings, and misrepresentations which reflect an, at best, ambiguous attitude to this country and, at worst, an unhappy compulsion on the part of some to denigrate virtues such as patriotism, honour and courage. (02.01.14)

The article then goes on to state that the war was 'just', that the Germans were to blame for their 'ruthless social Darwinism', 'pitiless approach to occupation', 'aggressively expansionist war aims' and 'scorn for the international order'. Douglas Haig was a patriotic leader, the Somme was a precursor to allied victory and Britain's role in the world was marked by nobility and courage. The author of the article was then Education Secretary Michael Gove. The article itself flies in the face of much reputable historiography concerning the First World War, and Gove provides very little support for his views, allegations and generalizations. There is insufficient time to unpick these here comprehensive analyses have been provided by Jeremy Paxman and Richard Evans, who both responded publicly and accused Gove of reckless and unsupportable revisionism. (Gallagher 2014; Evans 2014) What is of particular interest to this paper is the way in which Gove is able to manipulate a view of the First World War by appealing to a contemporary idea of 'Britishness', suggesting that if you have a negative or critical attitude to the former then you must have an 'at best ambiguous' attitude to the latter. He even goes so far as to suggest that Evans is against 'the very idea of honouring the sacrifice' of those who died in the war. In his response, Evans points out that he had done no such thing, but simply criticized Gove's 'redrafting of the national schools history curriculum to force schools to teach an uncritically celebratory narrative of English history.' (Guardian, 06.01.14) This gets to the nub of the problem - as far as Gove is concerned, you are either with Gove, or you are against Britain. There is nothing historical about his argument, but it is constructed according to the same logic of obligation and participation that underwrites the remembrance rituals. Despite their (to use Gove's phrase) 'at best ambiguous' relationship to the First World War, there is a public obligation to be seen to participate, otherwise one risks being seen as somehow disrespectful to the dead. But compliance with the ritual implicitly vindicates a proscribed attitude to past events that is neither from history, nor is it historical. Evans himself had, in fact, already anticipated this direction of Gove's logic in an earlier article, where he attacked the education secretary's biased and 'uncritical' history syllabus, drawn up in conjunction with the historian Simon Schama:

Gove, Schama and their allies are confusing history with memory. History is a critical academic discipline whose aims include precisely the interrogation of memory and the myths it generates. [...] For those in power, this makes history as a discipline not only useless but dangerous too. (Evans 2011: 12)

The syllabus was withdrawn and redrafted after a storm of criticism, but the logic that produced it remains firmly embedded, as I have shown, in the functions served by the remembrance rituals in contemporary Britain. These acts of cultural memory are (falsely) purported to connect the present to the past, and in doing so they muddy the waters of History by opening up events of the past to contemporary political machinations. This is anathema to Evans, who believes that History (as an academic discipline) should be protected from the vicissitudes of the present. For Gove, however, historical narratives provide a useful support to his political beliefs - so long as they are not interrogated, challenged or undermined. So long, in other words, as they are safeguarded from the scrutiny of historians.

I want to conclude by returning to the performed moment from Blood + Chocolate, which although it prompted this discussion, has been woefully neglected in its duration. There is, undeniably, a strong element of didacticism in the telling or being told to 'leave', because you do not 'belong'. It is equally undeniable, of course, that didacticism has been something I have strongly opposed in this paper - the didacticism of obligation to perform rituals with dubious claims to 'remembrance'. But is being told to leave any better than being obliged to stay? Certainly it is no more historical, it prompts no greater interrogation of or connection with history, and could even be said to let the individual off the hook or worse, promote an active 'forgetting' of the past since we do 
not belong there. An easy response would be to point to the allure of the forbidden - 'who are you to say that don't I belong here? why not?', which then prompts a retaliatory engagement by the affronted spectator. And undoubtedly, some of that rather juvenile indignation did inform my own interest in this subject. But more than this, there is a provocation, a stimulation that occurs when you are revealed to yourself as a trespasser - you are invited to consider your position in relation to the place where you trespass. In doing so, you cannot rely upon the kind of received wisdom which, when formalised into ritual, may lend credence, authority and power to the kind of politically motivated revisionism that has been demonstrated in this paper through the writings of Michael Gove. As we simultaneously move further away from the First World War and embed it ever more rigidly into our national discourses, it is my belief that invitations to think and to question such as that offered by Blood + Chocolate, will become increasingly valuable in guarding against such manipulations. And in this, there is therefore a specifically theatrical rejoinder to the troubling societal role currently occupied by the British remembrance ritual.

\section{BIBLIOGRAPHY}

Bond, E. (2012) 'Riot War Justice and History',

<www.edwardbond.org/Comment/riotwarjusticehistory.doc> [Accessed 19 April 2016].

Donaldson, P. (2006) Ritual and Remembrance: The Memorialization of the Great War in East Kent. Cambridge: Cambridge Scholars Press.

Evans, R.J. "The Wonderfulness of Us (the Tory Interpretation of History) LRB Vol 33: No. 6. 17 March 2011.

Evans, R.J. "Michael Gove shows his ignorance of history - again” Guardian, 6 January 2014.

Fisk, R. 7 'The wearing of poppies helps us to avoid searching for the meaning of war'. Independent, 7 November 2013.

Gallagher, P. "Jeremy Paxman reopens war of words with Michael Gove over the WW1 centenary". Independent, 13 March 2014.

Gove, M. "Why does the Left insist on belitting true British heroes?" Daily Mail, 1 January 2014.

Halbwachs, Maurice (1992). On Collective Memory. Edited, Translated and with an Introduction by Lewis. A. Coser. Chicago: University of Chicago Press.

Hirsch, Marianne (2006) "Testimonial Objects: Memory, Gender and Transmission" in Poetics Today 27:2. Porter Institute for Poetics and Semiotics.

McRae, J. (1915) "In Flanders Fields”, in Ferguson, M., Mary Jo Salter, Jon Stallworthy, ed. (1970) The Norton Anthology of Poetry: Fourth Edition. New York: W. W. Norton \& Company, Inc.

Schechner, Richard (2009) “A Ritual Seminar Transcribed” in Interva(le)s 4/5. Centre Interdisciplinaire de Poétique Appliquée.

Lehmann, Hans-Thies, (2013) “A Future for Tragedy?” in Postdramatic Theatre and the Political. London: Bloomsbury Methuen Drama. 